\title{
Pollutant dispersal in groundwater and sediments of gaining and losing river reaches affected by metal mining
}

\author{
Urszula Aleksander-Kwaterczak $^{1} \cdot$ Dariusz Ciszewski $^{1}$
}

Received: 19 March 2015/Accepted: 25 July 2015/Published online: 6 January 2016

(C) The Author(s) 2015. This article is published with open access at Springerlink.com

\begin{abstract}
The presented work couples groundwater and sediment chemistry in the metal mining-polluted Przemsza River valley in southern Poland to reveal regularities in pollutant distribution and to relate them to sedimentary processes and surface water/groundwater exchange. Ten piezometers were installed in transects across the lowgradient, meandering losing river reach and in the incised, channelised gaining reach. At each sampling site, cores of sediments were sampled for heavy metals and groundwater samples were collected over a year, for standard physicochemical analysis as well as $\mathrm{Zn}, \mathrm{Pb}, \mathrm{Cd}, \mathrm{Mg}$ and $\mathrm{Fe}$. In the losing river reach, the magnitude of pollution of groundwater in the levee zone was similar to that in the river, and declined in the backswamp. In the levee zone of the incised reach, minimum groundwater pollution adjacent to the highly polluted river was related to gaining relatively clean groundwater. In the losing reach, the dispersal of heavy metals in the levee zone is controlled mainly by overbank accumulation of polluted sediments. Post-depositional changes of metal concentrations in profiles of the losing reach indicate the important role of groundwater in metal dispersal. In the gaining river reach, the redistribution of metals in the profiles was not ascertained due to a much lower groundwater table.
\end{abstract}

Keywords Pollution - Floodplain · Groundwater · Heavy metals $\cdot$ Metal mining $\cdot$ River sediments

Urszula Aleksander-Kwaterczak

aleksa@geol.agh.edu.pl

1 AGH University of Science and Technology, 30 Mickiewicza Av., 30-059 Krakow, Poland

\section{Introduction}

Mine waters constitute a major pollution source for the aquatic environment. Mining effluents may affect the quality of surface and groundwater as well as sediments over distances of tens of kilometres from their discharge points (Aleksander-Kwaterczak and Helios-Rybicka 2009; Liu et al. 2011). They interact with natural river water, changing the content of metals, macroions, suspended matter, oxygen, $\mathrm{pH}$ or temperature, and through the deposition of fine sediment, they increase the heavy metal content in a river bed and on a floodplain (Byrne et al. 2012; Ciszewski et al. 2012). Moreover, alluvial rivers may exchange waters with floodplains, changing their groundwater quality (Naiman et al. 2005).

Depending on the nature of the hydraulic gradients, groundwater flow direction within the floodplain alluvium can be dominated by components parallel or perpendicular to the channel (Larkin and Sharp 1992). The bidirectional exchange of water between groundwater and river flow takes place during both flood flows and low flows (Naiman et al. 2005; Vivoni et al. 2006). Groundwater flow directions in the groundwater/river water exchange zone, called the hyporheic zone, are controlled by channel geometry under low and intermediate flow conditions with losing, gaining and flow-through or parallel flow, and by floodplain morphology during floods (Woessner 2000). In general, most river reaches are groundwater-fed, where discharge increases by gaining water from a catchment, while many lowland, low-gradient meandering rivers lose water to the floodplain (Krause et al. 2007; Cardenas 2009). These reaches can play an important role in the transformation of pollutants transported with river water, depending on the scale of river/groundwater interactions (Gandy et al. 2007). 
Interactions between groundwater and surface water bodies in river valleys are complex and depend on many factors including topography, geology, climate and the position of the surface water body relative to the groundwater flow system (Winter et al. 1998; Sophocleous 2002). The interface of groundwater and surface water along the river valley is characterised by large gradients of nutrients and trace metal concentrations, and contrasting environmental conditions (Boulton et al. 1998). Contaminants are transformed in reversible reactions such as ion exchange, adsorption or precipitation/dissolution, and irreversible reactions such as biodegradation (Lamers et al. 2006). The transformation rate is controlled primarily through the content of clay minerals, organic matter and oxides/hydroxides with the highest sorption and exchange capacity (Appelo and Postma 2005).

There are numerous examples of channel and overbank sediment contamination through metal mining, with sequences of heavy metals in overbank sediments reflecting mining history, reported from almost all regions of the world (Owens et al. 1999; Hudson-Edwards 2003; Ciszewski et al. 2012; Lecce and Pavlowsky 2014). However, while the role of sediments in contaminant transfer from the river is well known, groundwater dispersal of contaminants within a floodplain is poorly recognised. In the presented studies, it is approached through investigations of metal distribution in alluvial sediments and groundwaters of the Przemsza River floodplain, in relation to groundwater contamination at variable distances from the mine-contaminated Przemsza River in southern Poland.

The catchment of this river has for centuries been extensively mined for coal and non-ferrous metal ores. The upper course of this river, called Biala Przemsza, still receives a large proportion of waters from the lead and zinc ore mines, averaging $50 \%$ of the river discharge. This diminishes flow amplitude, reducing the probability of overbank flows to extreme flood cases and control metal concentrations in bed sediments over the $40 \mathrm{~km}$ long reach (Ciszewski 2001). The lower reach of the Przemsza River also receives untreated effluents from the large industrial area of southern Poland-Upper Silesia. The river water is highly polluted with organic components of black coal, numerous plants and domestic effluents. River-borne contaminants can penetrate the alluvial floodplain as it is composed of uniform sands. Investigations focused on two reaches with contrasting groundwater exchange mechanisms: the losing reach of the Biala Przemsza River and the gaining reach of the Przemsza River. Obtained metal and macroion distribution was explained in terms of the main dispersal mechanisms.

\section{Area of research}

The Przemsza River is the left side tributary of the Vistula River, which is the main river of Poland, with over $1000 \mathrm{~km}$ of length. The catchment of the Przemsza River, with over $2000 \mathrm{~km}^{2}$ of surface area, drains the eastern part of the Upper Silesia Upland and the western part of the Cracow Upland, which is dominated by carboniferous rocks. Rocks form relatively narrow cuestas; 300-400 m a.s.l., separated by wider basins situated at 250-300 a.s.1., and are filled with fluvioglacial deposits. The valley of the Przemsza River consists of a series of short and relatively steep, narrow reaches alternating with up to $1 \mathrm{~km}$ wide valley reaches of lower gradient filled with fluvioglacial deposits (Ciszewski 2001). In the investigated middle reach, the Biala Przemsza is a meandering, low-gradient river with low banks accompanied by a backswamp zone. Plants are typical of midEuropean riparian communities, with a domination of black alder, ash, willow, as well as turf grass and reeds in locations that are lower and more distant from the channel. At valley margins, there are small oxbow lakes with natural aquatic plant communities. The radii of river meanders vary between 50 and $100 \mathrm{~m}$, while the radius of the investigated compound meander is approximately $300 \mathrm{~m}$. Lateral channel stability, documented by topographical maps over the period of more than the last 100 years, favoured levee accumulation in a zone $2-30 \mathrm{~m}$ wide and up to $1 \mathrm{~m}$ higher than the rest of the floodplain. The average discharge of the Biala Przemsza River equals $4 \mathrm{~m}^{3} / \mathrm{s}$ in this reach, and half of it originates from one of the largest lead and zinc mines in Europe-the "Boleslaw" Mining and Metallurgic Plants (ZGH).

Downstream the right side tributary of the Przemsza, called Czarna Przemsza, the river receives large amounts of salts and metals from industrial wastewaters, coal mining, steel plants and untreated domestic effluents from the eastern part of Upper Silesia, which is inhabited by ca. 2 million people. The average discharge of the Przemsza River in its lower, investigated reach equals $15 \mathrm{~m}^{3} / \mathrm{s}$. The river has a straightened channel of uniform width and stone revetments as a result of 19th/20th century channelisation. The topography of its floodplain is weakly differentiated, mostly due to artificial levelling during channelisation works. The near-bank zone is formed of low levee and associated sparse willow bushes, while remnants of the preregulating channel are preserved in more distant locations. In the sampling area, the left side floodplain is confined by embankments of up to a width of approximately $200 \mathrm{~m}$. 


\section{Methods}

\section{Sampling}

Studies of floodplain sediment and groundwater pollution were carried out on the floodplain in the meandering reach of the Biala Przemsza River and in the channelised reach of the Przemsza River. In both river reaches, sediments were drilled at points located in cross sections perpendicular to the river channel. At each sediment sampling point, one piezometer was installed. The upper cross section was located $2 \mathrm{~km}$ downstream of Slawkow town, in the middle course of the river. Five vertical profiles, up to $1.3 \mathrm{~m}$ deep, were sampled there to a depth of around $0.3-0.5 \mathrm{~m}$ below the average groundwater level. Two profiles represented a levee zone at a distance of around 3 and $30 \mathrm{~m}$ from the channel, two further profiles situated around 100 and $200 \mathrm{~m}$ from the channel represented the backswamp zone, and one profile was sampled from the small oxbow lake (Fig. 1). The floodplain height equalled $1.0 \mathrm{~m}$ at the channel bank, declined gently to around $40 \mathrm{~cm}$ in the outer levee zone and was only ca. $0-20 \mathrm{~cm}$ higher than the average ground water level in the backswamps. The lower transect of the Przemsza River floodplain crosses the levee zone, which is around $50 \mathrm{~m}$ wide, as well as the former channel, filled with sediments to a height exceeding the average groundwater level. The edges of the channel are highly visible in the floodplain topography. Five piezometers have been installed in this almost $200 \mathrm{~m}$-long cross section on the left river bank, in increasing distances from the channel. Two of the piezometers represent the levee zone while the three farthest ones away represent the paleochannel. Profile depths varied there between 2.7 and $2.3 \mathrm{~m}$ in the near-bank zone, while within the paleochannel, they decreased from around $1.2 \mathrm{~m}$ to around $0.3 \mathrm{~m}$ near the flood dyke. Sediments were drilled with a percussion corer and sediment cores were divided into individual samples according to their structural and textural changes.

\section{Water analysis}

Groundwater from the piezometers as well as river water was sampled six times at variable water stages over a period of 1 year. For groundwater analysis, at least three piezometer volumes of water were purged before sampling, using a low-rate submersible pump attached to a polyethylene hose. Values of $\mathrm{pH}$ and conductance were established in situ. Samples were filtered before analysis through $0.45 \mu \mathrm{m}$ filters and concentrations of $\mathrm{Cl}^{-}, \mathrm{NO}_{3}{ }^{-}, \mathrm{SO}_{4}{ }^{2-}$, $\mathrm{PO}_{4}{ }^{3-}, \mathrm{CO}_{3}{ }^{2-}$ and macroions $(\mathrm{Ca}, \mathrm{Mg}, \mathrm{Na}, \mathrm{K})$ were determined within $48 \mathrm{~h}$ using Ion Chromatography

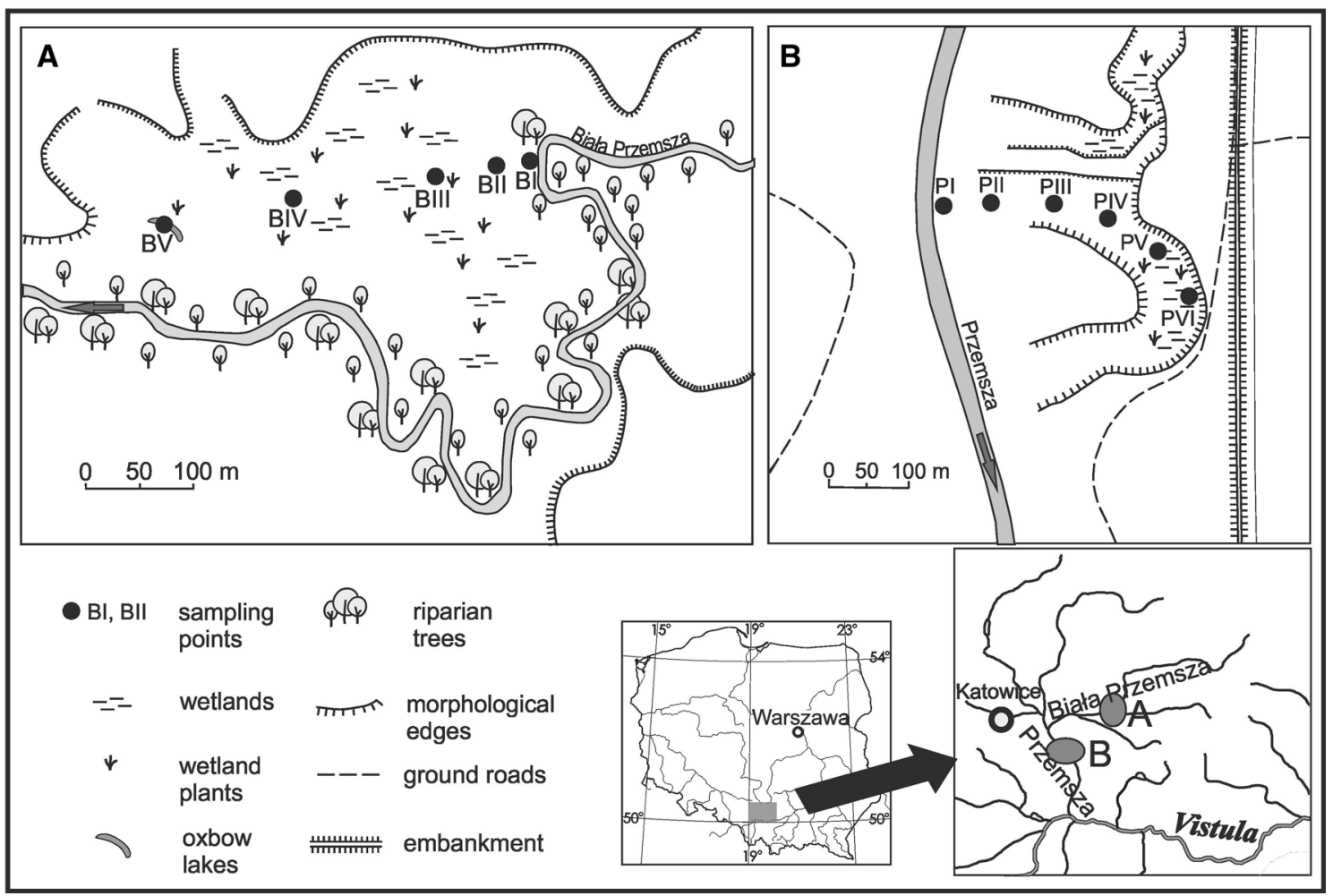

Fig. 1 Location of the research area and sampling point locations 
(DIONEX 1000). Standard reference materials (Canadian waters Hamilton-20) were employed to determine the accuracy of anion analyses. For analysis of $\mathrm{Zn}, \mathrm{Cd}, \mathrm{Pb}, \mathrm{Cu}$, $\mathrm{Fe}$ and $\mathrm{Mn}$, waters were filtered onsite through syringe filters $0.45 \mu \mathrm{m}$, acidified to $\mathrm{pH}$ below 2 with ultrapure $\mathrm{HNO}_{3}$ and measured with an inductively coupled plasmamass spectrometer (Perkin Elmer ELAN 6100) in a certified Hydrogeochemical Laboratory according to standard certified analytical quality control procedure (PN-EN ISO 17294-1: 2007).

\section{Sediment/soil analysis}

Values of $\mathrm{pH}$ were measured onsite while the density of sediment and water content was analysed right after transport to the laboratory. The concentration of carbonates was determined using the Scheibler method (PN-ISO 10693: 2002). Organic matter content was estimated as losses on ignition at $550{ }^{\circ} \mathrm{C}(\mathrm{LOI})$. The content of the silt clay fraction of sediments $(<0.063 \mathrm{~mm})$ was determined after wet-sieving. $0.5 \mathrm{~g}$ of this fine fraction was analysed for heavy metal content by dissolution in $10 \mathrm{~cm}^{3}$ of $65 \%$ $\mathrm{HNO}_{3}$ and $2 \mathrm{~cm}^{3}$ of $30 \% \mathrm{H}_{2} \mathrm{O}_{2}$ using a microwave digestion technique. The concentrations of metals were determined using a flame atomic absorption spectrometer (F-AAS). Metal analyses were performed according to standard certified analytical quality control procedure. Reagent blanks and certified reference materials were used to control analytical accuracy. Results from ICP-MS were confirmed with F-AAS measurements, which attested to the very good analytical quality of all analysed elements.

\section{Results}

\section{Losing river reach}

\section{Water}

The groundwater level varied in a small range over the investigated period. In the near-bank zone, the water level varied within a range of $1.0-1.1 \mathrm{~m}$ and rose in the snow melting period to $0.9 \mathrm{~m}$. In the outer levee, the water level was at a depth of $0.25-0.35 \mathrm{~m}$ and in the melting period it rose to $0.15 \mathrm{~m}$. In the backswamp zone, the water level varied in a range of $0.0-0.1 \mathrm{~m}$ over the year. Generally, the mean content of most of the investigated macroions in the groundwater of the upper reach decreased with distance from the channel. This was not the case for carbonates, which peaked in the distal part of the levee zone (BP2, Table 1). The groundwater was generally weakly acidified, while the $\mathrm{pH}$ of the river water was permanently alkaline ( $\mathrm{pH}$ about 8). Conductance of the river water, with a mean of $900 \mu \mathrm{S} \mathrm{cm}^{-1}$, was only slightly higher than in groundwater around $3 \mathrm{~m}$ from the channel (BP1); it decreased outside the levee and rose in the oxbow lake (Table 1). The content of most of the macroions was slightly higher in the river than in the groundwater at the river bank, but dropped in the case of $\mathrm{Na}$ and $\mathrm{K}$. In the backswamps, concentrations of macroions were usually much lower than in the levee zone and were weakly differentiated, particularly for sulphates, nitrates and potassium. Waters in the oxbow lake had higher mineralisation and contained more ions, except for heavy metals, than in the backswamps located farthest from the channel (BP4). The highest $\mathrm{Pb}$ concentrations were markedly higher in the river than in the floodplain, while the average content of $\mathrm{Zn}, \mathrm{Cd}$ and $\mathrm{Cu}$ increased immediately at the river bank. Also, the content of Fe and $\mathrm{Mn}$ increased with distance from the river. However, concentrations of iron equalled $1.5 \mathrm{mg} / \mathrm{L}$ only in the swampy location of high average groundwater level (BP3), while manganese peaked at around $0.35 \%$ closer to the river, i.e. in the distal part of the levee (BP2, Table 1). The ionic ratio $\left(\mathrm{Na}^{+}+\mathrm{K}^{+}\right) /\left(\mathrm{Ca}^{2+}+\mathrm{Mg}^{2+}\right)$ has the highest value in the river water and gradually decreases with distance from the riverbed and rises again around the oxbow lake (Table 1). It can show a progressive change in the chemical composition of groundwater from the river channel to more distal parts of the floodplain. The highest value of $\mathrm{SO}_{4}{ }^{2-} / \mathrm{Cl}^{-}$ratio was observed in the backswamp (BP/3, Table 1) and oxbow (BP/5, Table 1) as this fact may indicate that in these places sulphate reduction takes place.

\section{Sediments/alluvial soils}

Sediments from the near-bank zone (BP1-levee top zone, Fig. 1) were weakly acidic to neutral (6.6-7.1). The topmost stratum $(0-5 \mathrm{~cm})$ contained the largest amounts of organic matter (about $13 \%$ ), carbonates (about $10 \%$ ) and heavy metals. They dropped over the next $20-30 \mathrm{~cm}$ and then varied much less with depth. The $20-30 \mathrm{~cm}$ thick surface layer of the levee also contained the highest content of silt clay fraction. Concentrations of $\mathrm{Zn}, \mathrm{Cd}$ and $\mathrm{Pb}$ in this top stratum were the highest of the whole analysed cross section. Below, the metal concentrations decreased 3-10 times and small metal peaks appeared at the average groundwater level at a depth of $1 \mathrm{~m}$ (Fig. 2, Table 2). The distribution of heavy metals, organic matter and carbonates in the other profile located $25 \mathrm{~m}$ from the channel resembled that of the profile closest to the channel. However, the content of fine fraction was higher and reached $35 \%$ in the upper layer. Again, small metal peaks occurred at the average groundwater level at a depth of approximately $1 \mathrm{~m}$. Backswamp sediments were composed mostly of silts (up to $75 \%$ ) with high organic matter content (up to 
Table 1 Physico-chemical parameters of groundwater in the investigated losing river reach

\begin{tabular}{|c|c|c|c|c|c|c|c|}
\hline \multirow[t]{3}{*}{ Parameter (unit) } & \multirow[t]{3}{*}{ Concentration/value } & \multicolumn{6}{|c|}{ Biala Przemsza River } \\
\hline & & \multirow{2}{*}{$\begin{array}{l}\text { River } \\
\text { BP0 }\end{array}$} & \multicolumn{2}{|c|}{ Levee zone } & \multicolumn{2}{|c|}{ Backswamps } & \multirow{2}{*}{$\begin{array}{l}\text { Oxbow } \\
\text { BP/5 }\end{array}$} \\
\hline & & & $\mathrm{BP} / 1$ & $\mathrm{BP} / 2$ & $\mathrm{BP} / 3$ & $\mathrm{BP} / 4$ & \\
\hline \multirow[t]{2}{*}{$\mathrm{pH}$} & Min & 7.73 & 6.64 & 6.45 & 6.12 & 5.86 & 6.40 \\
\hline & Max & 8.00 & 7.05 & 6.84 & 6.73 & 6.59 & 7.09 \\
\hline \multirow[t]{3}{*}{ Conductance $\left(\mu \mathrm{S} \mathrm{cm}^{-1}\right)$} & Min & 739 & 664 & 373 & 406 & 204 & 261 \\
\hline & Max & 1006 & 1155 & 903 & 499 & 285 & 455 \\
\hline & Art mean & 900 & 845 & 744 & 424 & 232 & 353 \\
\hline \multirow[t]{3}{*}{ Chlorides $\left(\mathrm{mg} \mathrm{dm}^{-3}\right)$} & Min & 25.48 & 19.41 & 11.78 & 7.22 & 5.70 & 11.41 \\
\hline & Max & 34.94 & 30.43 & 24.72 & 18.68 & 18.03 & 33.58 \\
\hline & Art mean & 29.87 & 24.68 & 21.25 & 13.45 & 12.87 & 20.37 \\
\hline \multirow[t]{3}{*}{ Carbonates $\left(\mathrm{mg} \mathrm{dm}^{-3}\right)$} & Min & 221.67 & 143.60 & 162.82 & 128.39 & 76.85 & 105.06 \\
\hline & Max & 397.66 & 455.51 & 635.47 & 272.03 & 138.89 & 210.23 \\
\hline & Art mean & 286.52 & 311.78 & 465.93 & 213.31 & 102.88 & 162.75 \\
\hline \multirow[t]{3}{*}{ Sulphates $\left(\mathrm{mg} \mathrm{dm}^{-3}\right)$} & Min & 210.83 & 154.04 & 43.04 & 9.59 & 4.51 & 8.19 \\
\hline & Max & 274.70 & 334.51 & 63.55 & 73.08 & 56.63 & 64.93 \\
\hline & Art mean & 240.19 & 217.28 & 50.74 & 46.00 & 33.10 & 33.12 \\
\hline \multirow[t]{3}{*}{ Nitrates $\left(\mathrm{mg} \mathrm{dm}^{-3}\right)$} & Min & 5.93 & 0.29 & 0.05 & 0.03 & 0.02 & 0.05 \\
\hline & Max & 10.58 & 21.43 & 1.08 & 0.33 & 0.55 & 6.31 \\
\hline & Art mean & 8.55 & 6.86 & 0.27 & 0.19 & 0.16 & 1.29 \\
\hline \multirow[t]{3}{*}{ Phosphates $\left(\mathrm{mg} \mathrm{dm}^{-3}\right)$} & Min & 0.007 & 0.003 & 0.002 & 0.005 & 0.001 & 0.002 \\
\hline & $\operatorname{Max}$ & 0.035 & 0.016 & 0.052 & 0.015 & 0.005 & 0.015 \\
\hline & Art mean & 0.013 & 0.005 & 0.011 & 0.006 & 0.002 & 0.005 \\
\hline \multirow[t]{3}{*}{$\mathrm{N}-\mathrm{NH}_{4}\left(\mathrm{mg} \mathrm{dm}^{-3}\right)$} & Min & 0.157 & 0.025 & 0.016 & 0.068 & 0.103 & 0.061 \\
\hline & Max & 0.944 & 0.967 & 0.335 & 0.392 & 1.199 & 0.776 \\
\hline & Art mean & 0.434 & 0.418 & 0.110 & 0.188 & 0.393 & 0.249 \\
\hline \multirow[t]{3}{*}{ Sodium $\left(\mathrm{mg} \mathrm{dm}^{-3}\right)$} & Min & 18.63 & 10.99 & 2.91 & 5.65 & 4.95 & 5.42 \\
\hline & Max & 25.66 & 19.02 & 11.10 & 7.92 & 7.08 & 11.63 \\
\hline & Art mean & 21.91 & 13.14 & 8.39 & 7.16 & 5.74 & 8.26 \\
\hline \multirow[t]{3}{*}{ Potassium $\left(\mathrm{mg} \mathrm{dm}^{-3}\right)$} & Min & 3.713 & 0.860 & 0.947 & 0.940 & 1.070 & 1.226 \\
\hline & Max & 7.337 & 2.802 & 2.100 & 1.885 & 2.193 & 7.441 \\
\hline & Art mean & 5.063 & 1.980 & 1.585 & 1.451 & 1.505 & 3.686 \\
\hline \multirow[t]{3}{*}{ Calcium (mg dm ${ }^{-3}$ ) } & Min & 106.15 & 90.14 & 53.13 & 50.90 & 26.23 & 37.61 \\
\hline & Max & 140.64 & 165.01 & 152.25 & 61.72 & 33.90 & 65.56 \\
\hline & Art mean & 121.59 & 124.59 & 120.73 & 56.48 & 29.30 & 49.72 \\
\hline \multirow[t]{3}{*}{ Magnesium ( $\mathrm{mg} \mathrm{dm}^{-3}$ ) } & Min & 30.76 & 22.79 & 11.29 & 11.46 & 6.51 & 6.92 \\
\hline & Max & 43.01 & 41.11 & 31.07 & 14.18 & 8.10 & 10.51 \\
\hline & Art mean & 36.99 & 31.22 & 24.53 & 12.42 & 7.03 & 8.37 \\
\hline \multirow[t]{3}{*}{$\mathrm{Cd}\left(\mu \mathrm{g} \mathrm{dm}^{-3}\right)$} & Min & 1.716 & 0.941 & 0.014 & 0.057 & 0.027 & 0.013 \\
\hline & Max & 2.939 & 28.98 & 0.298 & 0.569 & 0.246 & 1.698 \\
\hline & Art mean & 2.174 & 7.700 & 0.102 & 0.230 & 0.115 & 0.352 \\
\hline \multirow[t]{3}{*}{$\mathrm{Pb}\left(\mu \mathrm{g} \mathrm{dm}{ }^{-3}\right)$} & Min & 23.59 & 3.01 & 0.33 & 0.79 & 0.80 & 0.05 \\
\hline & Max & 107.40 & 54.06 & 4.36 & 15.31 & 11.25 & 4.64 \\
\hline & Art mean & 53.96 & 18.70 & 2.01 & 6.89 & 5.75 & 1.83 \\
\hline \multirow[t]{3}{*}{$\mathrm{Cu}\left(\mu \mathrm{g} \mathrm{dm}^{-3}\right)$} & Min & 1.422 & 1.325 & 0.289 & 0.578 & 0.519 & 0.060 \\
\hline & Max & 2.912 & 4.517 & 2.285 & 2.731 & 2.069 & 5.567 \\
\hline & Art mean & 2.074 & 3.289 & 1.206 & 1.367 & 1.363 & 2.096 \\
\hline
\end{tabular}


Table 1 continued

\begin{tabular}{|c|c|c|c|c|c|c|c|}
\hline \multirow[t]{3}{*}{ Parameter (unit) } & \multirow[t]{3}{*}{ Concentration/value } & \multicolumn{6}{|c|}{ Biala Przemsza River } \\
\hline & & \multirow{2}{*}{$\begin{array}{l}\text { River } \\
\text { BP0 }\end{array}$} & \multicolumn{2}{|c|}{ Levee zone } & \multicolumn{2}{|c|}{ Backswamps } & \multirow{2}{*}{$\begin{array}{l}\text { Oxbow } \\
\text { BP/5 }\end{array}$} \\
\hline & & & $\mathrm{BP} / 1$ & $\mathrm{BP} / 2$ & $\mathrm{BP} / 3$ & $\mathrm{BP} / 4$ & \\
\hline \multirow[t]{3}{*}{$\mathrm{Zn}\left(\mu \mathrm{g} \mathrm{dm}{ }^{-3}\right)$} & Min & 803.1 & 973.1 & 10.00 & 10.33 & 61.27 & 1.22 \\
\hline & Max & 12,502 & 1539.1 & 189.9 & 366.27 & 727.80 & 455.56 \\
\hline & Art mean & 1025.5 & 1186.3 & 49.42 & 126.13 & 206.39 & 102.62 \\
\hline \multirow[t]{3}{*}{$\operatorname{Mn}\left(\mu \mathrm{g} \mathrm{dm}{ }^{-3}\right)$} & Min & 154.7 & 174.8 & 596.2 & 136.5 & 198.8 & 17.5 \\
\hline & Max & 210.7 & 2478.6 & 3627.3 & 975.3 & 590.2 & 530.7 \\
\hline & Art mean & 174.9 & 1294.4 & 2144.7 & 664.7 & 324.9 & 274.9 \\
\hline \multirow[t]{3}{*}{$\mathrm{Fe}\left(\mu \mathrm{g} \mathrm{dm}^{-3}\right)$} & Min & 45.1 & 61.9 & 3704.5 & 6423.6 & 249.9 & 106.4 \\
\hline & Max & 402.6 & 7385.9 & 13,076 & 20,955 & 11,482 & 3162.2 \\
\hline & Art mean & 160.6 & 2382.6 & 7844.0 & 15,028 & 6965.9 & 996.3 \\
\hline \multirow[t]{2}{*}{$\left(\mathrm{Na}^{+}+\mathrm{K}^{+}\right) /\left(\mathrm{Ca}^{2+}+\mathrm{Mg}^{2+}\right)$} & Min & 0.163 & 0.105 & 0.060 & 0.081 & 0.184 & 0.149 \\
\hline & Max & 0.180 & 0.106 & 0.072 & 0.094 & 0.221 & 0.251 \\
\hline \multirow[t]{2}{*}{$\mathrm{SO}_{4}^{2-} / \mathrm{Cl}^{-}$} & Min & 0.121 & 0.091 & 0.389 & 0.620 & 0.318 & 0.454 \\
\hline & Max & 0.127 & 0.126 & 0.274 & 0.682 & 0.411 & 0.580 \\
\hline
\end{tabular}
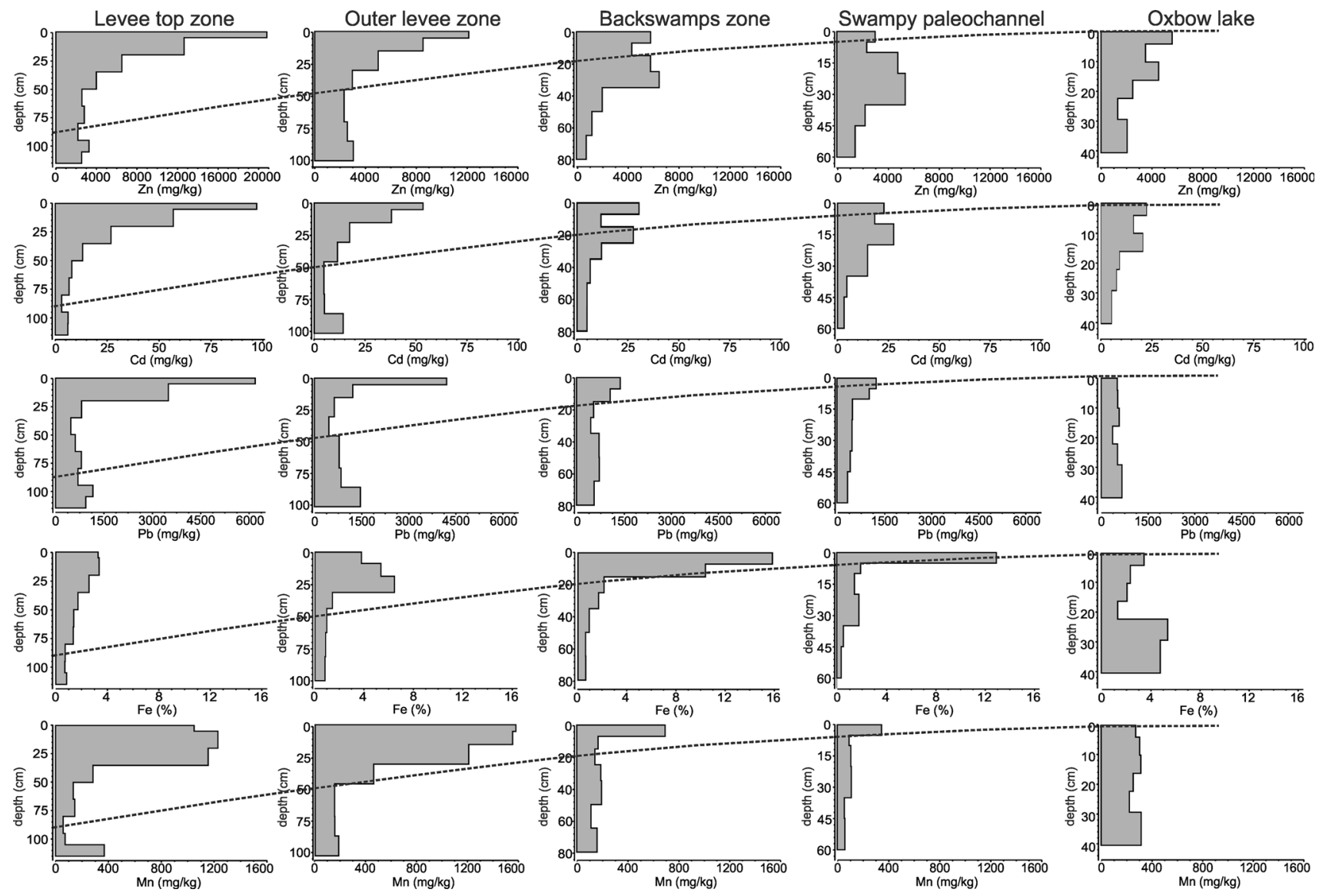

Fig. 2 Changes in heavy metals content in floodplain sediments of the Biala Przemsza River (dotted lines indicate average groundwater table level during study period) 
Table 2 Physico-chemical parameters of soils and sediments in the investigated cross section of the Biala Przemsza River

\begin{tabular}{|c|c|c|c|c|c|c|c|c|c|c|c|c|}
\hline \multirow[t]{2}{*}{ Core } & \multirow[t]{2}{*}{ Values } & \multirow{2}{*}{$\begin{array}{l}\text { Density } \\
\left(\mathrm{g} / \mathrm{cm}^{3}\right)\end{array}$} & \multirow[t]{2}{*}{$\mathrm{pH}$} & \multirow{2}{*}{$\begin{array}{l}\text { fr. }<0.063 \mathrm{~mm} \\
(\%)\end{array}$} & \multirow{2}{*}{$\begin{array}{l}\text { Water } \\
(\%)\end{array}$} & \multirow{2}{*}{$\begin{array}{l}\text { LOI } \\
(\%)\end{array}$} & \multirow{2}{*}{$\begin{array}{l}\text { Carbonates } \\
(\%)\end{array}$} & \multicolumn{5}{|c|}{ Metal (mg/kg) } \\
\hline & & & & & & & & $\mathrm{Cd}$ & $\mathrm{Pb}$ & $\mathrm{Zn}$ & $\mathrm{Fe}$ & Mn \\
\hline \multirow{5}{*}{$\begin{array}{l}\mathrm{BP} / 1 \\
n=9\end{array}$} & Minimum & 1.02 & 6.60 & 7.45 & 16.98 & 1.56 & 1.11 & 3.138 & 489.3 & 2163 & 6859 & 59.91 \\
\hline & Maximum & 1.87 & 7.09 & 33.20 & 28.40 & 12.64 & 9.24 & 100.6 & 6431 & 20,813 & 33,036 & 1297 \\
\hline & Art. mean & 1.48 & - & 20.65 & 21.94 & 4.81 & 2.82 & 25.77 & 1749 & 6362 & 17,416 & 526.4 \\
\hline & Median & 1.51 & - & 23.00 & 23.26 & 2.93 & 1.59 & 8.209 & 833.6 & 3259 & 13,623 & 298.3 \\
\hline & STD & 0.29 & - & 10.18 & 4.40 & 4.22 & 2.66 & 33.16 & 1999 & 6355 & 10,369 & 523.2 \\
\hline \multirow{5}{*}{$\begin{array}{l}\mathrm{BP} / 2 \\
n=7\end{array}$} & Minimum & 1.12 & 5.24 & 1.50 & 34.81 & 6.89 & 1.17 & 4.740 & 459.1 & 2304 & 8248 & 152.0 \\
\hline & Maximum & 1.52 & 7.09 & 8.80 & 73.92 & 43.14 & 19.64 & 53.86 & 4223 & 12,121 & 66,297 & 1585 \\
\hline & Art. mean & 1.38 & - & 4.22 & 49.84 & 18.07 & 5.61 & 20.71 & 1377 & 5215 & 28,760 & 757.9 \\
\hline & Median & 1.46 & - & 2.65 & 42.50 & 9.03 & 2.03 & 14.30 & 849.5 & 3037 & 14,502 & 460.7 \\
\hline & STD & 0.17 & - & 2.88 & 15.93 & 16.26 & 7.03 & 18.46 & 1301 & 3742 & 24,440 & 668.3 \\
\hline \multirow{5}{*}{$\begin{array}{l}\mathrm{BP} / 3 \\
n=8\end{array}$} & Minimum & 1.08 & 4.52 & 4.30 & 43.97 & 8.99 & 1.40 & 4.854 & 442.2 & 761.7 & 6335 & 111.5 \\
\hline & Maximum & 1.44 & 6.50 & 20.90 & 77.93 & 44.12 & 8.29 & 30.49 & 1364 & 6487 & 163,980 & 694.2 \\
\hline & Art. mean & 1.26 & - & 13.60 & 65.56 & 25.94 & 5.24 & 14.01 & 762.3 & 3773 & 47,564 & 236.5 \\
\hline & Median & 1.21 & - & 13.85 & 70.43 & 25.63 & 5.81 & 11.72 & 699.3 & 4328 & 17,353 & 166.8 \\
\hline & STD & 0.14 & - & 6.03 & 13.09 & 12.44 & 2.58 & 10.74 & 330.5 & 2404 & 62,665 & 203.8 \\
\hline \multirow{5}{*}{$\begin{array}{l}\mathrm{BP} / 4 \\
n=6\end{array}$} & Minimum & 1.12 & 3.64 & 2.25 & 13.29 & 0.90 & 0.28 & 3.165 & 331.6 & 1427 & 3500 & 54.36 \\
\hline & Maximum & 1.70 & 6.25 & 5.96 & 82.61 & 58.55 & 8.20 & 27.50 & 1242 & 5373 & 127,537 & 345.0 \\
\hline & Art. mean & 1.34 & - & 3.87 & 50.52 & 24.32 & 3.67 & 15.13 & 662.1 & 3189 & 31,140 & 127.2 \\
\hline & Median & 1.24 & - & 3.55 & 55.79 & 17.11 & 3.70 & 16.45 & 481.5 & 2670 & 15,832 & 98.14 \\
\hline & STD & 0.24 & - & 1.33 & 29.29 & 24.30 & 3.08 & 9.757 & 374.0 & 1558 & 47,652 & 109.1 \\
\hline \multirow{5}{*}{$\begin{array}{l}\mathrm{BP} / 5 \\
n=6\end{array}$} & Minimum & 1.20 & 4.20 & 0.18 & 12.30 & 0.22 & 0.23 & 5.499 & 363.4 & 1314 & 13,214 & 222.3 \\
\hline & Maximum & 2.30 & 6.55 & 5.44 & 78.45 & 14.02 & 5.25 & 23.49 & 662.7 & 5623 & 53,941 & 315.4 \\
\hline & Art. mean & 1.80 & - & 2.71 & 48.56 & 7.02 & 2.27 & 14.16 & 525.3 & 3259 & 32,353 & 279.4 \\
\hline & Median & 1.80 & - & 2.95 & 51.23 & 7.46 & 2.07 & 13.16 & 521.2 & 3005 & 29,152 & 287.1 \\
\hline & STD & 0.39 & - & 2.18 & 12.30 & 5.77 & 1.88 & 7.529 & 97.44 & 1619 & 16,066 & 37.51 \\
\hline
\end{tabular}

$44 \%)$. Values of $\mathrm{pH}$ decreased from 6.5 in the upper part to 4.5 in the rest of the profile. Except for Fe content, which exceeds $16 \%$ at the surface, metal concentrations in the backswamp zone were generally lower and more weakly differentiated than in the levee profiles. Sediments taken from the oxbow lake were very fine, especially up to a depth of $35 \mathrm{~cm}$, with content of silt clay fraction varying from 35 to $46 \%$. The value of $\mathrm{pH}$ decreased from 6.6 in the upper strata to more acidic at greater depth (4.5). Concentrations of heavy metals in the surface strata of the lake bottom were lower than in the swampy location of the previous site (BP4), but the content of Fe in the subsurface sediment strata was much higher than at the surface (Fig. 2, Table 2).

\section{Gaining river section}

\section{Water}

The groundwater level varied over the investigated period in a wider range than in the upper investigated reach. At both points of the levee zone, the water level varied within a range of 2.2-2.6 $\mathrm{m}$ and rose in the summer to $1.9 \mathrm{~m}$. In the proximal part of the paleochannel infill, the groundwater level varied between 0.8 and $1.1 \mathrm{~m}$ and in the summer it rose to $0.3 \mathrm{~m}$. In the rest of the paleochannel, the water level varied in a range of $0.5-1.2 \mathrm{~m}$ and rose to $0.1-0.2 \mathrm{~m}$ in the summer. The large differences between most of the physicochemical parameters of the surface water and groundwater were a characteristic feature of the lower, investigated cross section of the Przemsza River. The value of river water $\mathrm{pH}$ varied around 7.5 over the investigation period, while the $\mathrm{pH}$ of groundwater was lower by 1 to even 2.5 units than in the river, and was generally higher in the near-bank zone than in the paleochannel. Conductance of the river water was around 4-7 times higher than that of groundwater, and also two times higher than in the river in the upper cross section. The concentration of sulphates and chlorides in the river was 4-16 times higher than in the groundwater; the content of nitrates in the river was as much as 200 times higher than in the floodplain, while phosphates and carbonates were 
2-3 times more abundant in the river than in the floodplain. In contrast to macro ion distribution, much higher concentrations of $\mathrm{Cd}, \mathrm{Pb}$ and $\mathrm{Zn}$ were found in the groundwater than in the river, especially in the levee zone. The concentration of Cd peaked at $32 \mu \mathrm{g} / \mathrm{dm}^{3}$, the content of $\mathrm{Pb}$ at $170 \mu \mathrm{g} / \mathrm{dm}^{3}$, and the content of $\mathrm{Zn}$ equalled $5720 \mu \mathrm{g} / \mathrm{dm}^{3}$. The content of $\mathrm{Fe}$ and $\mathrm{Mn}$ rose rapidly outside the levee and the highest values were observed in the swampy section of the paleochannel, with a high average water level (Table 3). The ionic ratio $\left(\mathrm{Na}^{+}+\mathrm{K}^{+}\right) /\left(\mathrm{Ca}^{2+}+\mathrm{Mg}^{2+}\right)$ has the highest value in the river water and decreases rapidly in the floodplain area while the highest value of $\mathrm{SO}_{4}{ }^{2-} / \mathrm{Cl}^{-}$ratio was observed in the swampy section of the paleochannel (Table 3). This fact may indicate that in this area sulphate reduction takes place in the greatest extent.

\section{Sediments/alluvial soils}

Sediments from the levee top zone (P1, Fig. 1), around $3 \mathrm{~m}$ from the river channel, were alkaline in the upper layer $(\mathrm{pH}$ about 7.7) and strongly alkaline in the deeper part of the core (pH to 9.0). Fine-grained, sandy silt sediments with organic matter content up to $30 \%$ comprised the upper $70 \mathrm{~cm}$ strata. The lowest levels were dominated by fine-grained sands with an organic matter content of around $5 \%$. The highest content of heavy metals was observed at a depth of $150 \mathrm{~cm}$ and some cadmium and manganese anomalies were also observed at the surface. Sediments in the outer levee zone, represented by profile $\mathrm{P} 2$, were much more acidic, with $\mathrm{pH}$ values ranging between 4.8 and 6.4. Strata of fine-grained sands were intercalated with sediments with higher content of silt clay fraction and organic matter content. Strata enriched with organic matter were characterised by $\mathrm{pH}$ values lower than their coarsegrained counterpart. Concentrations of heavy metals in this profile were generally lower but unevenly distributed throughout the core, with higher metal content in the organic strata. Sediments filling the paleochannel, represented by profiles P3, P4 and P5, were weakly acidic and acidic ( $\mathrm{pH}$ from 5.2 to 6.8), and contained larger amounts of organic matter in the top layer than in the previous profiles. The higher contamination of the top 10-30 cm of sediment strata than the lower lying deposits was a characteristic feature of the metal distribution. Metal concentrations generally decreased with distance from the river in the surface $20-30 \mathrm{~cm}$ of this infill, and peaks of some metals appeared at lower levels, where water table fluctuations were more frequently observed (Fig. 3, Table 4).

\section{Discussion}

The investigated reaches were selected to represent different planform channel geometries, which control the pattern of flood sediment dispersal, floodplain topography and groundwater flow direction. Infiltration of the river water into the floodplain in the upper reach (Biala Przemsza) was anticipated based on the presence of permeable sandy sediments filling the river valley, a flat and wide valley bottom with high groundwater level, and a rapidly changing river flow direction. The beginning of the studied cross-section (BP, Fig. 1) perpendicular to the cutbank was established at the upstream part of the compound meander, where the river changes its flow from downvalley toward the valley slope direction at an angle of over $90^{\circ}$ (Fig. 1). Considering the small channel gradient over this river reach (around $1.5 \%$ ), the river must lose its water laterally in the downvalley direction across the meander bend. The presence of a surface water/groundwater exchange zone within the meander bends of alluvial rivers is also predicted and considered in hydrological models (Kiel and Cardenas 2014). This phenomenon is obvious considering the very high groundwater level, almost equal to the ground surface, over the entire inner part of the meander bend, which is separated from the river by only a 20-30 m wide levee.

However, a variety of local-scale factors control the development and characteristics of the levee; its presence depends on the lateral river channel stability over medium timescales $\left(10^{2-3}\right.$ years $)$ and increases in size with drainage area and amount of suspended load (Hudson and Heitmuller 2003). Levees develop during floods along river banks and are formed due to contrasting flow velocities in the channel and over a floodplain (Wyżga and Ciszewski 2010). The levee dimensions along the Biala Przemsza River are several times lower and as much as ten times narrower than those of large lowland rivers, but their form resembles that of the largest ones with respect to their cross-sectional shape and a progressively declining lee slope. The persistence of the levee zone of the Biala Przemsza is related to long-lasting lateral channel stability, which is characteristic of low-gradient rivers with low energy flows. This stability is confirmed by the same contemporary channel course as observed at the end of the nineteenth century map, and is also suggested by the presence of dense alder carr, which stabilises channel banks. Undoubtedly, long-term channel stabilisation favours backswamp formation due to the blocking of surface drainage of that part of the floodplain by the levee. It results in the development of wetland plant communities with a relatively thick organic layer blanketing fine-grained deposits.

The investigated cross-section in the lower reach of the Przemsza represents a human-modified river with respect to its straightened course, stone bank reinforcements and weakly differentiated floodplain, as well as high water and sediment pollution. The near-bank zone was formed mainly artificially, particularly in the cross section studied, located 
Table 3 Physico-chemical parameters of groundwater in the gaining river section

\begin{tabular}{|c|c|c|c|c|c|c|c|}
\hline \multirow[t]{2}{*}{ Parameter (unit) } & \multirow[t]{2}{*}{ Concentration/value } & \multicolumn{6}{|c|}{ Przemsza River } \\
\hline & & River & $\mathrm{P} / 1$ & $\mathrm{P} / 2$ & $\mathrm{P} / 3$ & $\mathrm{P} / 4$ & $\mathrm{P} / 5$ \\
\hline \multirow[t]{2}{*}{$\mathrm{pH}$} & Min & 7.44 & 5.12 & 5.78 & 6.08 & 5.05 & 5.76 \\
\hline & Max & 7.68 & 5.89 & 5.90 & 6.63 & 5.71 & 6.46 \\
\hline \multirow[t]{3}{*}{ Conductance $\left(\mu \mathrm{S} \mathrm{cm}{ }^{-1}\right)$} & Min & 1332 & 204 & 358 & 347 & 175 & 206 \\
\hline & Max & 2410 & 262 & 450 & 430 & 231 & 258 \\
\hline & Art mean & 1743 & 234.5 & 404 & 376 & 197 & 226 \\
\hline \multirow[t]{3}{*}{ Chlorides $\left(\mathrm{mg} \mathrm{dm}^{-3}\right)$} & Min & 209.19 & 13.17 & 36.87 & 9.81 & 11.59 & 15.59 \\
\hline & Max & 517.92 & 32.13 & 45.03 & 28.37 & 17.77 & 24.85 \\
\hline & Art mean & 323.72 & 21.44 & 42.28 & 17.38 & 15.26 & 20.76 \\
\hline \multirow[t]{3}{*}{ Carbonates $\left(\mathrm{mg} \mathrm{dm}^{-3}\right)$} & Min & 209.45 & 47.22 & 108.57 & 143.19 & 70.01 & 79.34 \\
\hline & Max & 276.24 & 104.87 & 118.74 & 160.78 & 84.57 & 116.60 \\
\hline & Art mean & 237.44 & 68.49 & 112.49 & 153.15 & 79.89 & 98.20 \\
\hline \multirow[t]{3}{*}{ Sulphates $\left(\mathrm{mg} \mathrm{dm}^{-3}\right)$} & Min & 152.66 & 24.23 & 43.26 & 27.52 & 11.10 & 9.34 \\
\hline & Max & 298.94 & 55.62 & 58.45 & 48.01 & 28.24 & 28.54 \\
\hline & Art mean & 202.74 & 43.75 & 51.26 & 41.48 & 20.55 & 15.26 \\
\hline \multirow[t]{3}{*}{ Nitrates $\left(\mathrm{mg} \mathrm{dm}^{-3}\right)$} & Min & 5.58 & 0.18 & 0.09 & 0.02 & 0.06 & 0.02 \\
\hline & Max & 10.28 & 0.83 & 1.06 & 3.64 & 0.34 & 0.06 \\
\hline & Art mean & 8.28 & 0.46 & 0.51 & 1.12 & 0.14 & 0.04 \\
\hline \multirow[t]{3}{*}{ Phosphates $\left(\mathrm{mg} \mathrm{dm}^{-3}\right)$} & Min & 0.0110 & 0.001 & 0.004 & 0.005 & 0.001 & 0.002 \\
\hline & Max & 0.3488 & 0.030 & 0.012 & 0.015 & 0.032 & 0.081 \\
\hline & Art mean & 0.038 & 0.012 & 0.009 & 0.011 & 0.008 & 0.023 \\
\hline \multirow[t]{3}{*}{$\mathrm{N}-\mathrm{NH}_{4}\left(\mathrm{mg} \mathrm{dm}^{-3}\right)$} & Min & 0.900 & 0.080 & 0.240 & 0.824 & 0.143 & 0.063 \\
\hline & Max & 2.712 & 0.405 & 0.534 & 1.163 & 0.864 & 0.389 \\
\hline & Art mean & 1.723 & 0.249 & 0.373 & 0.990 & 0.552 & 0.164 \\
\hline \multirow[t]{3}{*}{ Sodium $\left(\mathrm{mg} \mathrm{dm}^{-3}\right)$} & Min & 132.01 & 9.74 & 17.06 & 12.18 & 11.97 & 14.61 \\
\hline & $\operatorname{Max}$ & 303.28 & 16.21 & 20.06 & 19.01 & 13.90 & 15.52 \\
\hline & Art mean & 165.64 & 12.15 & 18.09 & 14.06 & 12.94 & 14.97 \\
\hline \multirow[t]{3}{*}{ Potassium $\left(\mathrm{mg} \mathrm{dm}^{-3}\right)$} & Min & 11.855 & 1.319 & 1.751 & 2.267 & 2.531 & 3.003 \\
\hline & $\operatorname{Max}$ & 18.202 & 2.518 & 2.520 & 3.770 & 4.495 & 4.246 \\
\hline & Art mean & 13.355 & 2.000 & 2.213 & 2.971 & 3.744 & 3.703 \\
\hline \multirow[t]{3}{*}{ Calcium $\left(\mathrm{mg} \mathrm{dm}^{-3}\right)$} & Min & 104.55 & 21.32 & 50.13 & 46.59 & 18.73 & 24.65 \\
\hline & Max & 145.75 & 30.05 & 54.86 & 50.12 & 22.99 & 29.12 \\
\hline & Art mean & 118.42 & 26.87 & 51.78 & 48.94 & 21.30 & 26.49 \\
\hline \multirow[t]{3}{*}{ Magnesium $\left(\mathrm{mg} \mathrm{dm}^{-3}\right)$} & Min & 34.51 & 5.36 & 5.87 & 6.02 & 2.85 & 3.37 \\
\hline & Max & 58.74 & 6.31 & 8.30 & 6.87 & 3.44 & 4.33 \\
\hline & Art mean & 39.86 & 5.73 & 7.03 & 6.36 & 3.10 & 3.84 \\
\hline \multirow[t]{3}{*}{$\mathrm{Cd}\left(\mu \mathrm{g} \mathrm{dm}^{-3}\right)$} & Min & 0.015 & 0.329 & 13.697 & 0.166 & 0.082 & 0.000 \\
\hline & $\operatorname{Max}$ & 0.247 & 30.369 & 32.219 & 7.199 & 20.052 & 0.343 \\
\hline & Art mean & 0.141 & 11.970 & 23.556 & 3.151 & 4.429 & 0.098 \\
\hline \multirow[t]{3}{*}{$\mathrm{Pb}\left(\mu \mathrm{g} \mathrm{dm}^{-3}\right)$} & Min & 1.07 & 0.51 & 22.40 & 5.43 & 5.85 & 1.87 \\
\hline & Max & 4.42 & 33.39 & 44.93 & 20.99 & 170.6 & 10.97 \\
\hline & Art mean & 2.24 & 14.04 & 34.36 & 14.54 & 82.12 & 6.59 \\
\hline \multirow[t]{3}{*}{$\mathrm{Cu}\left(\mu \mathrm{g} \mathrm{dm}^{-3}\right)$} & Min & 1.486 & 0.280 & 1.430 & 0.485 & 0.360 & 0.394 \\
\hline & Max & 2.353 & 1.088 & 2.644 & 1.269 & 4.138 & 7.686 \\
\hline & Art mean & 1.962 & 0.638 & 1.897 & 0.773 & 2.673 & 2.366 \\
\hline \multirow[t]{3}{*}{$\mathrm{Zn}\left(\mu \mathrm{g} \mathrm{dm}{ }^{-3}\right)$} & Min & 81.8 & 3355.1 & 2670.7 & 746.01 & 348.1 & 7.2 \\
\hline & Max & 323.8 & 5719.4 & 3472.7 & 1633.5 & 1169.3 & 205.0 \\
\hline & Art mean & 214.1 & 4340.4 & 3016.9 & 1081.8 & 570.9 & 92.8 \\
\hline
\end{tabular}


Table 3 continued

\begin{tabular}{|c|c|c|c|c|c|c|c|}
\hline \multirow[t]{2}{*}{ Parameter (unit) } & \multirow[t]{2}{*}{ Concentration/value } & \multicolumn{6}{|c|}{ Przemsza River } \\
\hline & & River & $\mathrm{P} / 1$ & $\mathrm{P} / 2$ & $\mathrm{P} / 3$ & $\mathrm{P} / 4$ & $\mathrm{P} / 5$ \\
\hline \multirow[t]{3}{*}{$\operatorname{Mn}\left(\mu \mathrm{g} \mathrm{dm}^{-3}\right)$} & Min & 188.0 & 337.1 & 619.4 & 888.1 & 112.8 & 58.6 \\
\hline & Max & 477.5 & 509.8 & 1123.0 & 2535.1 & 338.8 & 654.7 \\
\hline & Art mean & 339.1 & 421.5 & 932.2 & 1369.4 & 174.5 & 262.7 \\
\hline \multirow[t]{3}{*}{$\mathrm{Fe}\left(\mu \mathrm{g} \mathrm{dm}^{-3}\right)$} & Min & 32.1 & 1278.6 & 7304.1 & 9844.6 & 3536.5 & 1312.0 \\
\hline & Max & 83.5 & 4997.8 & 9537.5 & 16,878 & 19,767 & 8943.5 \\
\hline & Art mean & 51.7 & 2815.8 & 8340.3 & 13,781 & 11,268 & 4629.2 \\
\hline \multirow[t]{2}{*}{$\left(\mathrm{Na}^{+}+\mathrm{K}^{+}\right) /\left(\mathrm{Ca}^{2+}+\mathrm{Mg}^{2+}\right)$} & Min & 1.035 & 0.415 & 0.336 & 0.275 & 0.672 & 0.591 \\
\hline & Max & 1.572 & 0.515 & 0.357 & 0.400 & 0.696 & 0.628 \\
\hline \multirow[t]{2}{*}{$\mathrm{SO}_{4}^{2-} / \mathrm{Cl}^{-}$} & Min & 0.577 & 1.731 & 1.173 & 1.692 & 0.957 & 0.599 \\
\hline & Max & 0.730 & 1.841 & 1.298 & 2.805 & 1.589 & 1.149 \\
\hline
\end{tabular}
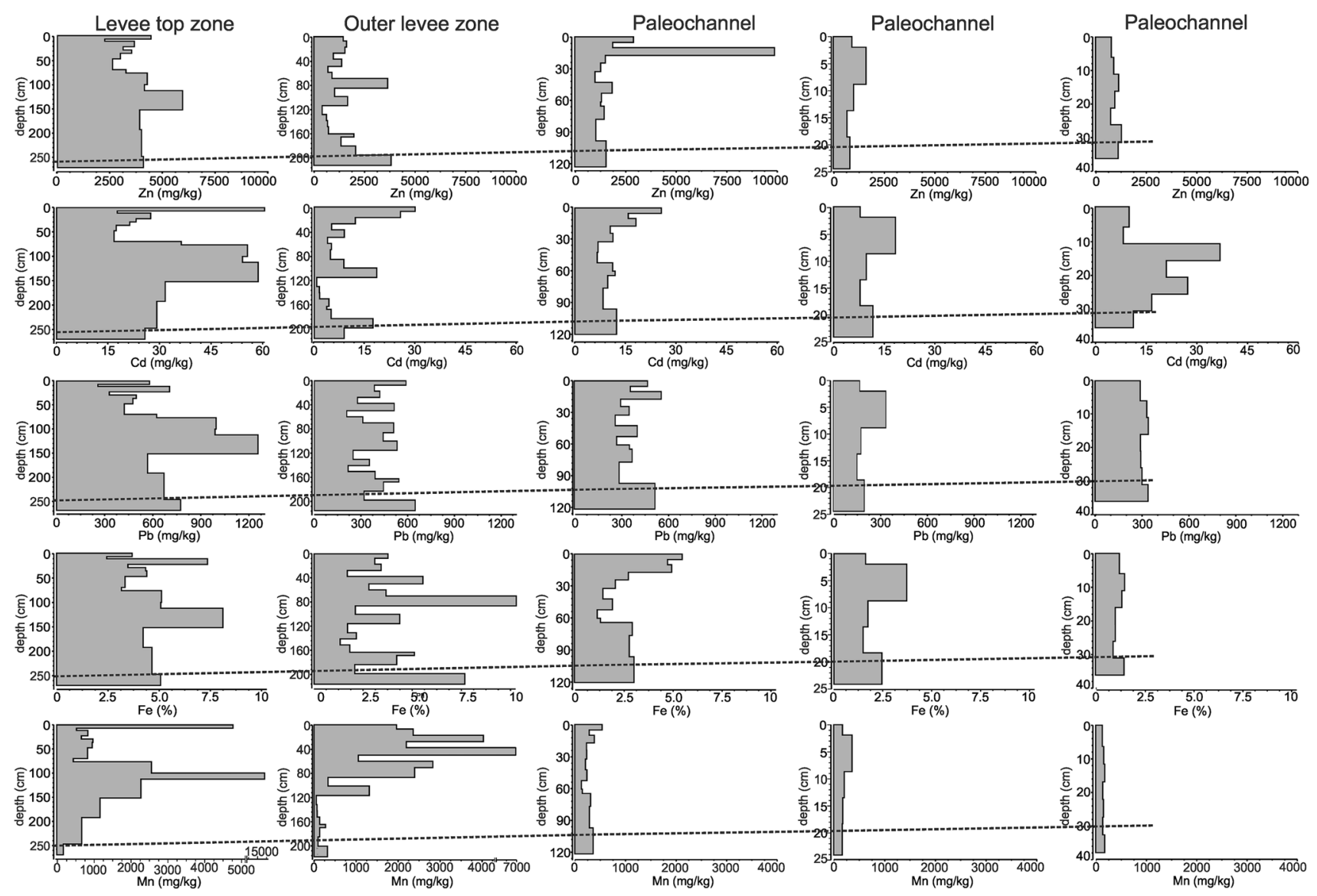

Fig. 3 Changes in heavy metals content in floodplain sediments of the Przemsza River (dotted lines indicate average groundwater table level during study period)

in this part of the former channel filled with ground mass excavated during channelisation works. This zone of the cross section limits the former channel from the river, making a closed floodplain depression outside (Fig. 1). The channelisation of a meandering alluvial river such as the lower Przemsza produces a higher gradient and increases stream power and channel incision. These channel changes, leading eventually to a lowering of the groundwater table in adjacent floodplains, were also observed in other rivers of the Carpathian piedmont (Ciszewski and Czajka 2015). Also, we could reasonably assume that Przemsza River, in its lower reach, drains groundwater due to 
Table 4 Physico-chemical parameters of soils and sediments in the investigated cross section of the Przemsza River

\begin{tabular}{|c|c|c|c|c|c|c|c|c|c|c|c|c|}
\hline \multirow[t]{2}{*}{ Core } & \multirow[t]{2}{*}{ Values } & \multirow{2}{*}{$\begin{array}{l}\text { Density } \\
\left(\mathrm{g} / \mathrm{cm}^{3}\right)\end{array}$} & \multirow[t]{2}{*}{$\mathrm{pH}$} & \multirow{2}{*}{$\begin{array}{l}\text { fr. }<0.063 \mathrm{~mm} \\
(\%)\end{array}$} & \multirow{2}{*}{$\begin{array}{l}\text { Water } \\
(\%)\end{array}$} & \multirow{2}{*}{$\begin{array}{l}\text { LOI } \\
(\%)\end{array}$} & \multirow{2}{*}{$\begin{array}{l}\text { Carbonates } \\
(\%)\end{array}$} & \multicolumn{5}{|c|}{ Metal (mg/kg) } \\
\hline & & & & & & & & $\mathrm{Cd}$ & $\mathrm{Pb}$ & $\mathrm{Zn}$ & $\mathrm{Fe}$ & $\mathrm{Mn}$ \\
\hline $\mathrm{P} / 1$ & Minimum & 1.00 & 7.18 & 0.38 & 4.63 & 0.32 & 0.13 & 14.98 & 0.00 & 1535 & 24,520 & 182 \\
\hline \multirow[t]{4}{*}{$n=13$} & Maximum & 1.91 & 9.04 & 99.00 & 78.01 & 30.79 & 27.11 & 55.10 & 1363 & 5966 & 81,491 & 15,099 \\
\hline & Art. mean & 1.59 & - & 34.47 & 28.38 & 9.94 & 4.48 & 31.75 & 523.0 & 3136 & 46,201 & 2432 \\
\hline & Median & 1.64 & - & 9.23 & 21.32 & 4.28 & 0.91 & 27.93 & 421.7 & 2774 & 43,607 & 977 \\
\hline & STD & 0.23 & - & 41.76 & 19.73 & 11.51 & 8.11 & 14.17 & 479.3 & 1299 & 16,242 & 4007 \\
\hline $\mathrm{P} / 2$ & Minimum & 1.35 & 4.80 & 0.11 & 0.02 & 0.06 & 0.11 & 0.000 & 209.9 & 370.6 & 12,802 & 55.46 \\
\hline \multirow[t]{4}{*}{$n=19$} & Maximum & 2.11 & 6.40 & 7.44 & 20.56 & 2.36 & 0.60 & 27.61 & 836.2 & 3599 & 103,743 & 6822 \\
\hline & Art. mean & 1.70 & - & 2.17 & 7.71 & 0.70 & 0.30 & 9.490 & 488.1 & 1223 & 36,189 & 1535 \\
\hline & Median & 1.74 & - & 1.33 & 5.62 & 0.50 & 0.29 & 7.420 & 481.8 & 1214 & 31,525 & 733.5 \\
\hline & STD & 0.21 & - & 2.07 & 6.43 & 0.63 & 0.16 & 7.756 & 178.1 & 736.3 & 23,186 & 1839 \\
\hline $\mathrm{P} / 3$ & Minimum & 1.21 & 5.53 & 0.31 & 12.69 & 0.14 & 0.11 & 3.17 & 99.57 & 853 & 11,462 & 123.7 \\
\hline \multirow[t]{4}{*}{$n=12$} & Maximum & 2.08 & 6.75 & 23.25 & 61.92 & 16.00 & 1.77 & 25.59 & 982.3 & 2464 & 54,330 & 513.5 \\
\hline & Art. mean & 1.72 & - & 8.20 & 23.61 & 4.11 & 0.57 & 12.39 & 438.9 & 1292 & 28,585 & 266.5 \\
\hline & Median & 1.76 & - & 4.82 & 15.77 & 1.13 & 0.29 & 11.53 & 435.3 & 1213 & 27,401 & 248.5 \\
\hline & STD & 0.31 & - & 7.99 & 16.11 & 5.94 & 0.59 & 5.91 & 216.8 & 436 & 14,493 & 106.6 \\
\hline $\mathrm{P} / 4$ & Minimum & 1.22 & 5.14 & 1.39 & 14.26 & 0.49 & 0.20 & 6.99 & 185.0 & 640 & 14,737 & 157.8 \\
\hline \multirow[t]{4}{*}{$n=5$} & Maximum & 1.95 & 6.02 & 54.82 & 55.54 & 14.79 & 2.26 & 16.40 & 985.4 & 1350 & 36,921 & 339.7 \\
\hline & Art. mean & 1.71 & - & 19.03 & 28.83 & 5.13 & 0.95 & 10.98 & 386.4 & 862 & 21,823 & 204.2 \\
\hline & Median & 1.84 & - & 5.39 & 17.36 & 0.74 & 0.23 & 8.73 & 242.0 & 778 & 17,175 & 166.8 \\
\hline & STD & 0.30 & - & 22.84 & 18.40 & 6.49 & 1.02 & 4.32 & 337.0 & 279 & 9212 & 77.24 \\
\hline $\mathrm{P} / 5$ & Minimum & 1.52 & 5.70 & 2.06 & 15.77 & 0.48 & 0.19 & 8.06 & 238.6 & 540 & 8515 & 107.9 \\
\hline \multirow[t]{4}{*}{$n=7$} & Maximum & 1.89 & 6.33 & 48.67 & 40.44 & 7.65 & 1.30 & 36.31 & 295.5 & 1015 & 14,078 & 147.2 \\
\hline & Art. mean & 1.72 & - & 15.72 & 25.47 & 3.04 & 0.62 & 17.51 & 276.3 & 769 & 11,396 & 126.2 \\
\hline & Median & 1.75 & - & 4.79 & 17.79 & 0.82 & 0.29 & 17.16 & 284.1 & 701 & 11,527 & 125.6 \\
\hline & STD & 0.13 & - & 17.78 & 10.55 & 3.15 & 0.50 & 9.86 & 20.77 & 163 & 2221 & 15.74 \\
\hline
\end{tabular}

channel incision by at least $1 \mathrm{~m}$, as a result of the channelisation. This leads to the conclusion that the Przemsza is a gaining river also in the cross section studied.

The assumptions regarding groundwater/surface water exchange processes in the riparian zone are confirmed by the relative changes in the chemical composition of water in the investigated cross sections. The very high content of the analysed chemical compounds in the levee zone, as compared to the rest of the cross section of the Biala Przemsza, is a characteristic feature of their distribution in the floodplain (Table 1). In particular, the drop in chloride content and conductivity between levee and backswamp indicates an intensive influx of surface water to the floodplain margin. The content of many of the investigated compounds in the river water is actually comparable to that observed immediately within the first few meters of the near-bank zone. Over the whole width of the levee, the content of calcium, magnesium and carbonates similar to or even higher than in the river can be related to the dissolution of dolomite particles originating from triassic dolomite outcrops, also observed in other drainage basins in the region (Ciszewski et al. 2012). The progressive increase of iron content from the river towards the backswamp is the other characteristic feature of the variability of water chemistry in the Biala Przemsza floodplain. High iron content in backswamp groundwater, around $1.5 \mathrm{mg} / \mathrm{L}$ on average, is well correlated with the highest iron content in surface sediments, at around 12-15\%. Swampy areas are typically abundant in iron because of widespread reducing conditions that favour the dissolution of iron compounds and precipitation when oxidisation is taking place, even producing in some locations strata of iron bog deposits (Crear et al. 1979; Lucassen et al. 2000). In the Biala Przemsza cross section, the direction of groundwater flow from the river and the increase in iron content, which could be correlated to the progressive oxygen consumption parallel to the increase in organic matter content, leads to maximum iron accumulation in the outer backswamp zone. Iron accumulation is certainly a long-term process also favoured by small water table fluctuations observed year- 
round, and the persistency of levee and backswamp zones. Changes in chemical composition and progressive oxygen depletion in the hyporheic zone typically induce zonation within meander bends, coupled with biochemical activity (Boano et al. 2010). However, in some losing reaches of heavily sewage-affected rivers, redox zonation can show inverted zonation from sulphate-reducing conditions, close to the river, over manganese and iron-reducing conditions to a mixed oxic/suboxic zone farthest from the channel (Sprenger and Lorenzen 2014).

The chemical composition of groundwater and its relative changes in the Przemsza cross section differs from that of the Biala Przemsza River. Moreover, the content of chlorides, sodium and potassium increases in the lower course of the river, mainly as a result of the discharge of salty waters from coal mines of the Upper Silesian mining district (Maksymiak-Lach et al. 2006). Also, total river water mineralisation rises towards the Biala Przemsza tributary from the intensively mined part of the basin. The content of the investigated metals (except of manganese) decreases, but sulphates and nitrates remain at similar levels to the upper section of the river. Despite the very high values of chlorides and mineralisation in the river water of the lower reach, they are still lower in the levee than in the levee of the upper cross section. At point P1, situated in the levee at the river bank, all the investigated values (except of zinc) are lower than both in the river and at point P2, situated farthest from the channel (Table 2). These relatively low values indicate a lack of reflux of river water towards the floodplain at average flow conditions and differ from those in the Biala Przemsza, where high values in the levee indicate a permanent influx of water from the river. The opposite distribution pattern of chemical constituents in the Przemsza reach results from the flow of groundwater towards the river and gaining conditions, which prevails at the investigated, average flows, confirming initial assumptions. Nevertheless, during prolonged periods of high river flows some loosing of water from the Przemsza River could be expected in this reach as well as gaining of water by the Biała Przemsza, during low water stages, which are rare due to constant, artificial water supply from the mine.

On many rivers, the gaining and loosing of water can be estimated by, e.g. detailed measurements of flow along the river, measurements of groundwater temperature, solute tracer or environmental tracer methods (Scanlon et al. 2002). However, the measurements of chemical constituents of both groundwater and surface water can also help to identify the extent of groundwater/surface water exchange processes in a relatively simply and inexpensive way (Kumar et al. 2009).

The measurement of chemical constituents of both groundwater and surface water can help identify the extent of groundwater/surface water exchange processes in a relatively simple and inexpensive way (Kumar et al. 2009). The spatial extent of such interactions is very evident in the investigated river reaches, with the contrasting compositions of river water and groundwater. The contrast is particularly great in the gaining Przemsza River reach as groundwater drained from the alluvial valley, over $1 \mathrm{~km}$ wide, is relatively weakly polluted. The higher content of many of the constituents farther from the Przemsza channel may be related to flooding, conditions favouring water stagnation in the floodplain depression, and thick sequences of polluted sediments. However, the lack of channel incision and the presence of wetland and natural geomorphic processes appear to play an important role in changes in groundwater chemistry in the Biala Przemsza cross section. The levee with the most active lateral exchange between river water and groundwater constitutes an important part of the hyporheic zone. There, water infiltrating from the river can change its properties during slow groundwater flow due to the reactive dissolution of minerals, deoxygenation, or other biochemically mediated processes controlling water chemistry transformation (Hoehn and Scholtis 2010). This suggests an important buffer capacity for the narrow strip of the floodplain (about 1/10). Farther from the channel, in a backswamp, recharge by rainfall and drainage from valley slopes most probably contribute to water chemistry.

Heavy metals are considered to be persistent contaminants which can be stored within floodplains for hundreds of years. These elements can be transferred from a channel on a floodplain during floods, both in solution as well as associated with sediments, and only in solution by bank filtration processes over a wide spectrum of flows lower than bankfull. Since the largest portion of the total metal load in rivers is transported in particulate matter, and metal concentrations in sediments are several orders of magnitude higher than in solution, overbank sediment accumulation plays a crucial role in the distribution of heavy metals in polluted river floodplains (Martin and Meybeck 1979; Miller 1997). Sediment-associated heavy metals are stored mainly in the levee zone with the highest average sediment accretion rate, which progressively decreases away from the channel (Ciszewski 2003). The same regularity is observed across the Biala Przemsza reach but peaks of metals drop, rather than progressively decline, outside the levee zone. In particular, peaks of lead, which is not a strongly mobile element, occur in the levee at the top of an approximately $20 \mathrm{~cm}$ thick layer, which could be attributed to the mining operation in the Biala Przemsza drainage basin since 1953. The obtained average accretion rate of the order of $3 \mathrm{~mm} /$ year would agree with the low levee height and reduced frequency of overbank flows due to the large and yearly constant proportion of mine water 
(Ciszewski 2001). This value generally agrees with accretion rates observed along the other lowland rivers (He and Walling 1996). The highest lead content occurs in the same layers as the peaks of zinc and cadmium, elements which also originate from the lead-zinc mine. This regularity did not take place in the backswamp as peaks of these metals occur at lower depths than in the levee. Considering the much lower accretion rate in the backswamp than in the levee, these must be secondary metal peaks. The post-depositional metal migration is related to the permanently high groundwater table, which fluctuates yearly in a small range within the subsurface strata (marked with a dashed line in Fig. 1). Small metal peaks, also just below the groundwater table in the levee zone, seem to confirm this conclusion, though likely the lateral component of the groundwater flow is at least just as important as the vertical one. Metal migration induced by groundwaters was also observed at the water table in other floodplains (Swennen and Van der Sluys 1998; Ciszewski et al. 2012, 2014). Between the upper and the lowest metal peaks in the levee, there is a transition strata with progressively declining metal concentrations. These changes may also be attributed to the post-depositional metal redistribution both during the periods of floodplain inundation and with rain waters. The importance of metal redistribution in the subsurface strata can be supported by high iron and manganese concentrations in a layer of greater thickness (as much as $0.5 \mathrm{~m}$ in the outer levee zone) than the one polluted by lead or zinc. Manganese and iron dissolution and reprecipitation are known as common mechanisms controlling the redistribution of associated metals in a hyporheic zone, as well cycling them in the water-sediment system of a river or a lake (Hudson-Edwards et al. 1998; Eggleton and Thomas 2004, Gandy et al. 2007).

While the role of groundwater in the post-depositional redistribution of heavy metals in the losing reach is important, metal redistribution in the gaining reach is less evident. Metal variability is irregular within consecutive profiles due to dumping and levelling of ground material during new bank construction across the former channel. The most recent sediment deposition could only be identified in the surface of the levee top zone, suggesting a very slow sediment accretion rate. This agrees with the presence of bank reinforcement, which precludes channel erosion and the low rate of mineral sediment transport in the Przemsza River (Lajczak 2012). The river transports mainly organic suspensions and floods usually leave only a very thin film of these materials in floodplain depressions. Overbank sediments are on average less polluted with heavy metals than in the Biala Przemsza, though to larger depths than in the levee zone. Considering that the groundwater table was reached at the bottom of the profiles, it is difficult to relate it to bottom metal peaks or to identify their regular changes with depth and distance from the river. It seems that in these profiles, groundwater plays a much less important role in the post-depositional redistribution of metals in sediments than in the losing river reach. These processes are limited by the lowering of the water table due to channel incision and overall opposite groundwater flow direction.

\section{Conclusions}

The presented investigations indicate river-to-floodplain contaminant transfer in wide and low-gradient valleys with meandering river reaches. These reaches are characterised by lateral loss of water from the channel, at least within meander bends, and by a permanently high water table favouring backswamp formation with wetland plant communities. The investigated reach of the Biala Przemsza River, which represents such conditions, is strongly contaminated with mine waters discharged from a lead-zinc mine. These conditions are conducive to the pollution of valuable wetlands over an approximately dozen kilometrelong river reach. Floodplain sediment and groundwater pollution are much higher in the levee zone than in the backswamp. Maximum zinc, cadmium and lead concentrations equal $2 \%, 100$ and $6000 \mathrm{mg} / \mathrm{kg}$, respectively. The content of many chemical constituents in the groundwater as high as in the river water testifies to an intensive efflux of water from the river. In general, sediment contamination and the content of heavy metals and macroions in groundwater decrease abruptly to quite low levels over a short distance between the levee and backswamps. However, the higher content of iron in the groundwater and sediment in the backswamp proves reducible iron dissolution and precipitation at the ground surface.

Metal distribution in the top part of the levee zone in the losing reach is controlled by slow overbank accumulation of the polluted sediment. Metal distribution in the lower sediment strata of the levee and in the backswamp is affected by the permanently high groundwater table and its fluctuations. This is evidenced by the peaks of some metals shifted down relative to the surface, the tails of the upper peaks and the appearance of peaks below the average water table.

The lower course of the Przemsza River is characterised by gaining water from the floodplain due to channelisationinduced channel incision. The levee accretion over a similar period of time is negligible as compared to the natural Biala Przemsza River reach. Heavy metal concentrations vary irregularly in the profiles and are unrelated to the average groundwater table, even at a depth of over $2.5 \mathrm{~m}$. The minimum groundwater pollution right at the river bank of this strongly polluted river reach was interpreted as an 
influx of water from the floodplain to the channel. The metal distribution in the profiles of this reach seems to be affected to a much lesser extent by fluctuations of the groundwater table than in the losing reach.

Acknowledgements The work was funded by the Ministry of Science and Higher Education grant no. 18.18.140.290 and University of Science and Technology in Krakow grant no. 11.11.140.199.

Open Access This article is distributed under the terms of the Creative Commons Attribution 4.0 International License (http://crea tivecommons.org/licenses/by/4.0/), which permits unrestricted use, distribution, and reproduction in any medium, provided you give appropriate credit to the original author(s) and the source, provide a link to the Creative Commons license, and indicate if changes were made.

\section{References}

Aleksander-Kwaterczak U, Helios-Rybicka E (2009) Contaminated sediments as a potential source of $\mathrm{Zn}, \mathrm{Pb}$, and $\mathrm{Cd}$ for a river system in the historical metalliferous ore mining and smelting industry area of South Poland. J Soils Sediments 9:13-22

Appelo CAJ, Postma D (2005) Geochemistry, groundwater and pollution. A.A. Balkema, Rotterdam, p 649

Boano F, Demaria A, Revelli R, Ridolfi L (2010) Biogeochemical zonation due to intrameander hyporheic flow. Water Resour Res 46(2):W02511

Boulton AJ, Findlay S, Marmonier P, Stanley EH, Valett HM (1998) The functional significance of the hyporheic zone in streams and rivers. Annu Rev Ecol Syst 29:59-81

Byrne P, Wood PJ, Reid I (2012) The impairment of river systems by metal mine contamination: a review including remediation options. Crit Rev Environ Sci Technol 42(19):2017-2077

Cardenas MB (2009) Stream-aquifer interactions and hyporheic exchange in gaining and losing sinuous streams. Water Res 45:W06429

Ciszewski D (2001) Flood-related changes in heavy metal concentrations within sediments of the Biala Przemsza River. Geomorphology 40:205-218

Ciszewski D (2003) Heavy metals in vertical profiles of the middle Odra River overbank sediments: evidence for pollution changes. Water Air Soil Pollut 143:81-98

Ciszewski D, Czajka A (2015) Human-induced sedimentation patterns of a channelized lowland river. Earth Surf Proc Landf 40:783-795

Ciszewski D, Kubsik U, Aleksander-Kwaterczak U (2012) Long-term dispersal of heavy metals in a catchment affected by historic lead and zinc mining. J Soils Sediments 12(9):1445-1462

Crear DA, Knox DW, Means JL (1979) Biogeochemistry of bog iron in the New Jersey pine barrens. Chem Geol 24:111-135

Eggleton J, Thomas KV (2004) A review of factors affecting the release and bioavailability of contaminants during sediment disturbance events. Environ Int 30:973-980

Gandy CJ, Smith JWN, Jarvis AP (2007) Attenuation of miningderived pollutants in the hyporheic zone: a review. Sci Total Environ 373:435-446

He Q, Walling DE (1996) Rates of overbank sedimentation on floodplains of British lowland rivers documented using fallout ${ }^{137}$ Cs. Geogr Ann 78A:223-234

Hoehn E, Scholtis A (2010) Exchange between a river and groundwater, assessed with hydrochemical data. Hydrol Earth Syst Sci Discuss 7:9023-9042
Hudson PF, Heitmuller FT (2003) Local- and watershed-scale controls on the spatial variability of natural levee deposits in a large fine-grained floodplain: lower Panuco Basin, Mexico. Geomorphology 56:255-269

Hudson-Edwards KA (2003) Sources, mineralogy, chemistry and fate of heavy metal-bearing particles in mining-affected river systems. Mineral Mag 67:205-217

Hudson-Edwards KA, Macklin MG, Curtis CD, Vaughan DJ (1998) Chemical remobilization of contaminant metals within floodplain sediments in an incising river system: implications for dating and chemostratigraphy. Earth Surf Proc Land 23:671-684

Kiel BA, Cardenas B (2014) Lateral hyporheic exchange throughout the Mississippi River network. Nat Geosci 7:413-417

Krause S, Bronstert A, Zehe E (2007) Groundwater-surface water interactions in a North German lowland floodplain- Implications for the river discharge dynamics and riparian water balance 347:404-417

Kumar M, Al R, Keshari AK (2009) Understanding the extent of interactions between groundwater and surface water through major ion chemistry and multivariate statistical techniques. Hydrol Process 23:297-310

Lajczak A (2012) Transport of suspended sediment by the Vistula River basin upstream of Kraków, southern Poland, and the human impact during the second half of 20th century. IAHS Publ 356:49-56

Lamers LPM, Loeb R, Antheunisse AM, Miletto M, Lucassen ECHET, Boxman AW, Smolders AJP, Roelofs JGM (2006) Biogeochemical constraints on the rehabilitation of wetland vegetation in river floodplains. Hydrobiologia 565:165-186

Larkin RG, Sharp JM (1992) On the relationship between river basin geomorphology, aquifer hydraulics, and ground-water flow direction in alluvial aquifers. Geol Soc Am Bull 104:1608-1620

Lecce SA, Pavlowsky RT (2014) Floodplain storage of sediment contaminated by mercury and copper from historic gold mining at Gold Hill, North Carolina, USA. Geomorphology 206:122-132

Liu W, Moran CJ, Vink S (2011) Quantitative risk-based approach for improving water quality management in mining. Environ Sci Technol 45:7459-7464

Lucassen ECHET, Smolders AJP, Roelofs JGM (2000) Increased groundwater levels cause iron toxicity in Glyceria fluitans (L.). Aquat Bot 66:21-327

Maksymiak-Lach H, Lach R, Caruk M (2006) Impact of hard coal mining restructuring on surface water salinity in the Upper Vistula catchment area. Mining Environ Res Rep 2:91-106 (in Polish)

Martin JM, Meybeck M (1979) Elemental mass balance of material carried by world major rivers. Mar Chem 7:173-206

Miller JR (1997) The role of fluvial geomorphic processes in the dispersal of heavy metals from mine sites. J Geochem Explor 58:101-118

Naiman RJ, Decamps H, McClain ME (2005) Riparia: ecology, conservation, and management of streamside communities. Elsevier Academic Press, Burlington

Owens PM, Walling DE, Leeks GJL (1999) Use of floodplain sediment cores to investigate recent historical changes in overbank sedimentation rates and sediment sources in the catchment of the River Ouse, Yorkshire, UK. Catena 36:21-47

PN-EN ISO 17294-1 (2007) Water quality: application of mass spectrometry with inductively coupled plasma (ICP-MS). pp $1-40$

PN-ISO 10693 (2002) Soil quality: determination of carbonatevolumetric method (In Polish)

Scanlon BR, Healy RW, Cook PG (2002) Choosing appropriate techniques for quantifying groundwater recharge. Hydrogeol $\mathrm{J}$ 10:19-39 
Sophocleous M (2002) Interactions between groundwater and surface water: the state of the science. Hydrogeol J 10:52-67

Sprenger C, Lorenzen G (2014) Hydrogeochemistry of urban floodplain aquifer under the influence of contaminated river seepage in Delhi (India). Aquat Geochem 20:519-543

Swennen R, Van der Sluys J (1998) Zn. Pb, Cu and As distribution patterns in overbank and medium-order stream sediment samples: their use in exploration and environmental geochemistry. J Geochem Explor 65:27-45

Vivoni E, Bowman RS, Wyckoff RL, Jakubowski RT, Richards KE (2006) Analysis of a monsoon flood event in an ephemeral tributary and its downstream hydrologic effects. Water Resour Res 42:W03404
Winter TC, Harvey JW, Franke OL, Alley WM (1998) Ground water and surface water a single resource. U.S. Geological Survey Circular 1139, Denver, Colorado

Woessner WW (2000) Stream and fluvial plain groundwater interactions: rescaling hydrogeologic thought. Ground Water 38(3):423-429

Wyżga B, Ciszewski D (2010) Hydraulic controls on the entrapment of heavy metal-polluted sediments on a floodplain of variable width, the upper Vistula River, southern Poland. Geomorphology 117:272-286 